\title{
Alternate paths to economic development: a comparative analysis of Brazil and India in the era of neoliberalism ${ }^{1}$
}

\author{
Caminhos alternativos ao desenvolvimento econômico: uma análise \\ comparativa entre Brasil e India na era do neoliberalismo
}

RAHUL A. SIROHI*

RESUMO: Este artigo compara e contrasta as estratégias de desenvolvimento brasileiro e indiano durante a era do neoliberalismo a partir de uma perspectiva de longo período. A economia brasileira tem tentado combinar os objetivos de redistribuição e equidade social com os objetivos de crescimento e produtividade. A Índia, por outro lado, tem seguido uma abordagem de maximização do crescimento em prol do desenvolvimento, embora preste pouca ou nenhuma atenção aos maiores objetivos do bem-estar humano. $\mathrm{O}$ artigo busca compreender a dinâmica da mudança econômica nas duas economias e tenta extrair os fatores institucionais e políticos que influenciaram essas abordagens.

PALAVRAS-CHAVE: Neoliberalismo; desenvolvimento humano; Brasil, Índia.

ABSTRACT: This paper compares and contrasts Brazilian and Indian strategies of development during the era of neo-liberalism from a long period perspective. The Brazilian economy has attempted to combine the goals of redistribution and social equity with the goals of growth and productivity. India on the other hand has pursued a growth maximizing approach to development, while paying little or no attention to the larger goals of human well-being. The article seeks to understand the dynamics of economic change in the two economies and attempts to draw out the institutional and political factors that have influenced these approaches.

KEYWORDS: Neoliberalism; Human Development; Brazil, India.

JEL Classifications: I00; H5; O5; O20.

\footnotetext{
${ }^{1}$ I would like to thank two anonymous referees. I am also grateful to Watson Institute, Brown University for inviting me to give a lecture on themes related to this paper. The suggestions from the participants have been invaluable. The suggestions made by the students and faculty at TISS Mumbai where this paper was presented, have also been useful. As always, the usual disclaimers apply.

* Assistant Professor, School of Development Studies, Tata Institute of Social Sciences, Mumbai, India. Email: rahul.sirohi84@gmail.com. Submitted: 8/July/2015; Approved: 21/March/2016.
} 


\section{INTRODUCTION}

The BRICS countries (Brazil, Russia, India, China and South Africa) account for 40 percent of the world population, 15 percent of world trade and 25 percent of the world GDP2 . Estimates suggest that this economic grouping is likely to overtake the G-6 countries in the coming decades (Cheng et al. $2007)^{3}$. Within this bloc, Brazil and India have emerged as important players in the world economy. They are major destinations for foreign investors and have become leading exporters of sophisticated goods and services. This paper analyzes the recent development trajectory of these two important constituents of the BRICS alliance.

At the surface there are striking similarities between the development strategies of Brazil and India. Both have embraced markets, but far from limiting their government much of their economic success is attributable to active state intervention. On the external front though trade barriers have been torn down, policy makers in both countries have not shied away from employing selective protection and regulation for strategic purposes (Ban and Blyth, 2013; McCartney, 2010). But underlying these similarities there are far reaching contrasts. Brazil's development policy has been successful in making growth inclusive. Though growth rates have been moderate the economy has been able to generate employment, high wages and has been successful in reducing poverty and inequality. In contrast, India's development model has been exclusively oriented towards maximizing growth. The strategy has delivered unprecedented growth rates- making India one of the fastest growing economies in the world- but this impressive performance has come at a large human cost, as poverty and deprivation have remained abysmally high and have probably even worsened over the neoliberal period.

At the very outset it needs to be mentioned that the two economies under analysis have had contrasting developmental experiences. Brazil is not only richer than India in per capita GDP terms, but is also far more urbanized. With these caveat in mind one, this paper seeks to understand the dynamics of economic change in the two economies during the neoliberal period and attempts to draw out the institutional and political factors that have influenced these approaches. The rest of the paper is arranged as follows: second and third sections describe the experiences of the two economies under neoliberalism. Fourth section builds on the previous sections and provides some insights into why the two regions followed very distinct development paths. The final section provides a brief conclusion of the main arguments.

\footnotetext{
${ }^{2}$ http://in.reuters.com/article/2013/03/26/brics-summit-factbox-idINDEE92P09120130326.

${ }^{3}$ In terms of GDP.
} 
By the 1970s- less than two decades after embarking on an ambitious project of economic development- the Indian economy was in the midst of a crisis. Industrial growth fell from an average of $6 \%$ in $1950-1970$ to $4.4 \%$ in the 1970s, dragging aggregate growth down to $2.9 \%$ per annum in $1970-80$ (Mohan, 2008). Economic stagnation had reached such proportions that according to an estimate by Isher Ahluwalia productivity in the industrial sector actually decelerated at a rate of -0.6 percent per annum in the period 1959 -1979 (quoted in Goldar, 1986). Faced with severe economic constraints Indian policy makers opted for a radical shift in the economic sphere. The new economic model adopted in the 1980's -and deepened after neo liberal reforms in 1990- sought to deregulate the domestic private sector and increase - albeit limitedly - economic integration with the world economy. Internally, licensing requirements in major industries like cement, telecommunications and automobiles were eased. Planning-era monopoly regulations were weakened and corporate taxes were slashed (Maiorano, 2014). On the external front, the rupee was devalued, tariff rates were reduced, import controls were dismantled and many sectors of the economy were opened up to foreign investments. The most crucial aspect of these changes was the gradual and sequential nature of reforms (Ahluwalia, 2002; Williamson and Zagha, 2002). Radical changes in labour laws, capital accounts or external liberalization were avoided in favour of a more cautious approach. The maneuverability and flexibility enjoyed by Indian policy makers was aided by the fact that in the run up to the reform process the economy was largely free of the kind of crippling crisis that many Latin American nations faced. The implications of these features are important and will be taken up in greater detail in the forth section.

It ought to be noted that none of these changes diminished the role of the state. Deregulation is therefore really a misnomer for describing India's new development path. Rather what occurred was a significant shift in the nature of state intervention (Kohli, 2006a, 2006b; Patnaik, 2007; Corbridge and Harriss, 2000). To understand this shift we may note certain features of the Nehruvian development regime. The post-colonial state was a product of two contradictory features. On the one hand the political clout of rural and industrial oligarchs ensured that state activism remained within strict limits when it came to issues like land reforms or large-scale income redistribution. On the other hand whatever the failings of the post-colonial state it was undoubtedly wedded to the idea of social and economic justice. What gave the state this egalitarian ideological bent was its specific historical legacy- It was the product of a democratic anti-colonial struggle; a struggle which had united Indians by promising freedom not just from imperial rule but freedom from servitude of all kinds (Sarkar, 2001, 2008; Guha, 2008; Patnaik, 2013). Therefore even though the 
post-colonial state may have been elitist, its historical legacy had also imparted an egalitarian streak to its functioning and ideologies. This historical specificity also meant that "[...] the motivation, the ideological inclinations, and the class background of the State personnel ensured that the State had a degree of autonomy both vis a vis imperialism and also vis-à-vis the domestic capitalists" (P. Patnaik, 2007 p. 12). The development path adopted in the late 1980's represented a break precisely from this sort of a state. Not only was there a dissolution of the anti-imperialist ethos but as Kohli argues, the success of the new regime of accumulation was contingent on an all-out "repression" of labour and a close alliance between the state and propertied classes. In a break from its past, key institutions of the state began to be manned by officials "... whose motivation is no different from that of the big bourgeoisie and financial interests..." (Patnaik, 2007 p. 13). Kohli calls this a "pro-business" model of development ${ }^{4}$. As an economic project, two tendencies of this model may be noted.

First, as Table 1 indicates, the economy has experienced substantial economic stability. Apart from a brief crisis in the early 1990's, growth has been stable and consistently high. The same table also shows that after 2000, growth rates have skyrocketed. Industries and services have performed very well, growing at an average rate of $7.4 \%$ and $8.5 \%$ respectively. Growth has been associated with a healthy increase in savings rates which have increased from an average of $24 \%$ of GDP in 1990-2000 to $32 \%$ of GDP in 2000-2012. It is important to note that the economy's investments have been financed largely from internal resources and therefore growth has not increased the economy's debt burden (McCartney, 2010). A comparison of Tables 1 and 2 reveals the robustness of debt figures for India.

Table 1: Macroeconomic Indicators, India

\begin{tabular}{|l|c|c|c|}
\hline & $1980-90$ & $1990-00$ & $2000-12$ \\
\hline GDP growth (annual \%) & 5.7 & 5.6 & 7.0 \\
\hline Agriculture, value added (annual \% growth) & 4.4 & 2.9 & 3.0 \\
\hline Industry, value added (annual \% growth) & 6.1 & 5.8 & 7.4 \\
\hline Services, etc., value added (annual \% growth) & 6.2 & 7.2 & 8.5 \\
\hline Total debt service (\% of GNI) & 1.6 & 2.9 & 2.4 \\
\hline $\begin{array}{l}\text { Total debt service (\% of exports of goods, } \\
\text { services and primary income) }\end{array}$ & 25.9 & 28.6 & 13.5 \\
\hline Gross savings (\% of GDP) & 21.1 & 24.1 & 31.8 \\
\hline
\end{tabular}

Source: World Development Indicators (Online)

\footnotetext{
${ }^{4}$ I fall back heavily on the theoretical analysis of Lavoie and Stockhammer (2012) on wage-led and profit-led growth regimes throughout this paper, though the terminology is not exactly identical.
} 
Table 2: Macroeconomic Indicators, Brazil

\begin{tabular}{|l|c|c|c|}
\hline & $1980-90$ & $1990-00$ & $2000-12$ \\
\hline GDP growth (annual \%) & 2.4 & 2.1 & 3.6 \\
\hline Agriculture, value added (annual \% growth) & 3.3 & 2.6 & 3.6 \\
\hline Industry, value added (annual \% growth) & 1.3 & 0.6 & 3.6 \\
\hline Services, etc., value added (annual \% growth) & $3.5^{\mathrm{a}}$ & $2.8^{\mathrm{b}}$ & 3.3 \\
\hline Total debt service (\% of GNI) & 5.4 & 4.5 & 6.1 \\
\hline $\begin{array}{l}\text { Total debt service (\% of exports of goods, } \\
\text { services and primary income) }\end{array}$ & 49.6 & 49.8 & 42.8 \\
\hline Gross savings (\% of GDP) & 19.8 & 15.5 & 16.3 \\
\hline
\end{tabular}

Source: World Development Indicators (Online)

a: data from 1980 to 1989

b: data from 1992 to 2000

Second, the new economic model has been successful in promoting high levels of growth but its actual impact on employment has been limited. There seems to be a broad agreement amongst students of the Indian economy that growth has been jobless (Bhaduri, 2008; Chandrasekhar and Ghosh, 2011). Joblessness is reflected in the declining employment elasticity which have fallen precipitously from 0.44 in 1999-2005 to 0.01 in 2004-2010 (Mehrotra et al. 2012. Figure 1 shows how employment population rates fare in the two countries. The figure clearly indicates Brazil's superior performance on this front. Though there are several reasons for these abysmal employment figures, one important factor is India's unique pattern of structural change which has favored high-tech services and technology-intensive manufacturing (Ghani, 2010; Kochhar et al. 2006). This capital intensive nature of structural change, while growth inducing, has been unsuccessful in absorbing the large pool of unskilled labour that exists in the countryside. Thus while the share of services accounted for $53 \%$ of GDP in 2010, its share in total employment was a mere $26 \%$. Agriculture on the other hand employed $55 \%$ of the labour force, but accounted for only $16 \%$ of GDP in the same year.

The cumulative result of the Indian pattern of development has been a relatively poor performance on the social front. In terms of labour market indicators one may note that starting from the 1980's there has been a steady decline in the share of wages in total national income (Chandrasekhar, 2010; ILO, 2010). Real wage growth which had touched 4.11 percent in 1982-1992, slumped sharply to -0.63 percent in 1999-2004 (Ahn, 2010). But this squeeze on the purchasing power of poorer households has forced many into more precarious occupations as informality has increased. Various indicators of hu- 


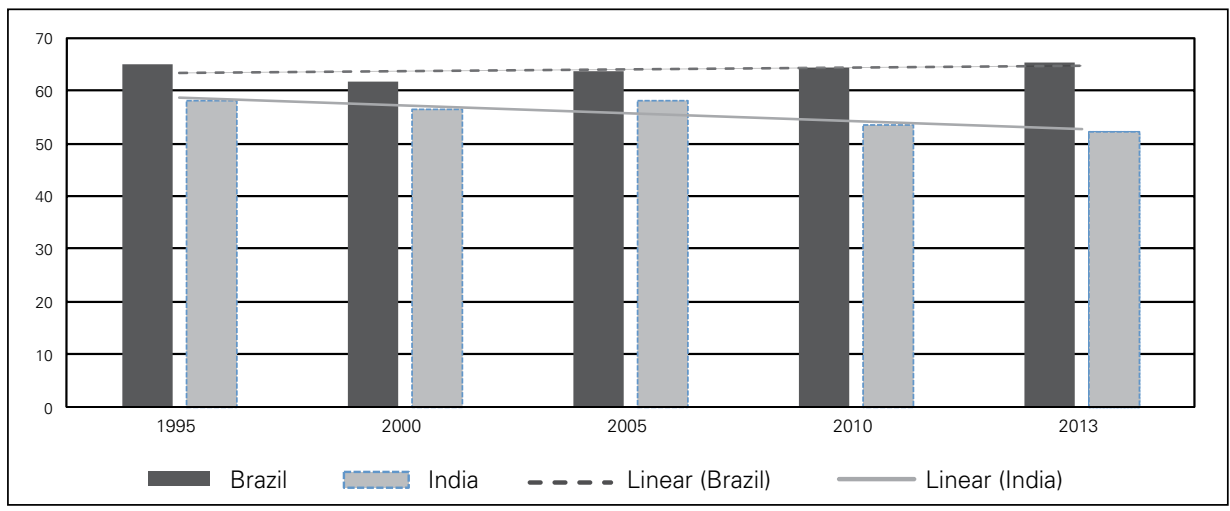

Source: World Development Indicators (Online)

man development strengthen the perception that India's growth experience has been exclusionary. UNICEF estimates that three out of ten stunted children in the world come from India and IFPRI's food hunger index places India along with countries facing "serious" rates of hunger. Though recent estimates suggest improvements in child malnutrition rates, 30 percent of children are still considered to be underweight (IFPRI, 2014). In rural areas the distress has reached epidemic proportions as indicated by a spate of farmer suicides. Crushed by debt and poverty over 180,000 farmers have committed suicide during 1997-2007 alone. For eminent journalist, P. Sainath, this is nothing short of "neoliberal terrorism" (Sainath 2009). As far as actual poverty trends are concerned, there is considerable controversy. There is a broad agreement that official poverty lines in India are too low (U. Patnaik, 2007, 2010; Ray, 2007; ADB, 2011). For example, using a poverty line of 1.35 USD per day, an estimated 740 million and individuals were below poverty line in 2004-2005, which is much higher than the official estimate of 300 million (ADB, 2011). As far as changes in poverty are concerned, opinions are divided. Favorable estimates suggest that poverty, however high, has nonetheless declined over the post-liberalization era (Ravallion, 2011; ADB, 2011). In contrast, calorie based estimates suggest that poverty has actually increased drastically (U. Patnaik, 2007, 2010; Ray, 2007). Utsa Patnaik's analysis indicates that poverty increased from 74.5 percent in 1993-1994 to 87 percent in 2004-2005 in rural regions and from 57 percent to 64.5 percent in urban regions in the same period.

It is important to stress that the description thus far has been a caricature of a very complex and non-linear process. In fact, in 2004 a coalition-government consisting of political parties with a heavy pro-labour tilt came to power and initiated several key policies. One of the most celebrated interventions of this period was the Mahatma Gandhi National Rural Employment Guarantee Scheme or the NREGS, the world's largest employment guarantee scheme. The 
program was celebrated for its extensive scale and reach. Policymakers and politicians were applauded by foreign and domestic observers. For some, interventions like these even signaled the end of India's flirtation with pro-capital policies (Maiorano, 2014). However, with the benefit of hindsight one can safely say that this short phase ended up only as a minor inflection point in an otherwise continuous consolidation of the pro-capital project. Take the example of the MNREGS itself. After initial bluster and excitement, successive governments have made concerted efforts towards weakening the program. Employment generated by the NREGS has fallen by $50 \%$ in the period 2009 and 2015 and budgetary allocations have been slashed by $30 \%$ over the same period (Drèze, 2015). Any lingering doubts about India's trajectory have been put to rest with the 2014 electoral victory of a government that has adopted a brazenly anti-labour stance. The government has threatened to dismantle the entire NREGS program itself.

The deprivations faced by the Indian working class are not innocent side effects of the pro-capital developmental approach; rather, inequality and poverty seem to have become crucial drivers of the Indian growth miracle. Bhaduri (2008) calls this "predatory growth": a process of accumulation that has become contingent on transfer resources from the poorest to the richest through economic and extra-economic means. These trends portend a dismal future for the most vulnerable sections of the Indian society. From this perspective, there is an immediate need to re-conceptualize social priorities and question the hegemony of elitist economic policies. Here the progress made by other societies can provide important lessons. The following section highlights how Brazil has been able to combine economic growth with the goals of social and economic justice. This inclusive growth has lifted millions out of hunger and has led to impressive improvements in human welfare.

\section{EQUITY AND PROGRESS: BRAZIL'S ROAD TO SOCIAL DEVELOPMENT}

Brazilian neoliberalism has to be analyzed in the context of the military dictatorship which lasted from 1964 to 1985 . When the authoritarian regime acquired power in the middle of the 1960s, Brazil was in the midst of a politi$\mathrm{cal}$ and economic crisis. The response of the army was swift and clinical- democratic rights were suspended and any viable political opposition was defanged. On the economic front the new regime embarked on a novel pattern of industrialization based on export promotion and greater integration with foreign capital (Baer, 2014). A distinctive feature of this new strategy was that it emphasized industries catering exclusively to the upper and middle classes (automobiles and consumer durables). Functionally this meant that the traditional emphasis on expanding home markets was effectively replaced by a strategy 
that concentrated on a narrower market made up of middle and upper class consumers (Bresser-Pereira, 1984). The new policy stance was to be supported by a concomitant exploitation and repression of labour (Seidman 1994).

By the 1980's Brazilian economy had developed a considerable industrial base and was capable of producing sophisticated goods. The contribution of agriculture to total GDP declined consistently while the share of manufacturing increased from $32.2 \%$ in 1960 to $40.9 \%$ in 1980 (Saad-Filho, 2010). As a share of total exports, the contribution of manufacturing increased from $2.6 \%$ in 1960 to $44.8 \%$ in 1980 (Abreu, 2004). But underlying all these achievements there were glaring flaws. Apart from the outright political and economic repression of labour, the military regime's economic policies were economically unsustainable. This was evident in the growing indebtedness that Brazilian industrialization came to be associated with. An industrialization model that was averse to expanding home markets inevitably came to rely on debt and "By 1979 debt service amounted to over 63 percent of the country's exports" (Baer, 2014 p. 82). Not only did this expose the economy to vagaries of financial flows but the increasing fiscal profligacy meant that industrial development in the 1970's became increasingly susceptible to inflation (Bresser-Pereira, 1990).

Given these inherent flaws the Brazilian model of development ran up against its limits. Massive bouts of inflation, reaching four digit numbers by the end of the 1980, crippled the economy. As gross capital formation and savings declined, so did the growth rates of GDP (See Table 2). Industrial growth rates declined in the first half of the 1980's before picking up slightly in the second half. On the political front the anti-labour policies of the authoritarian regime had created severe disenchantment amongst poorer sections of the Brazilian society and starting from 1978 a series of strikes rocked the Brazilian political landscape. This period also witnessed the rise of pro-labour parties like the Worker's Party (Partido dos Trabalhadores or PT) and a proliferation of social movements like the Landless Workers Movement (MST). These tumultuous political conditions together with the adverse economic fallouts of the crisis led to far reaching economic and political changes: In the political sphere, the 1980's marked an end of the military dictatorship and a transition towards democracy. In the economic sphere import substitution industrialization was abandoned and free market policies were officially adopted in the 1990s.

It may be noted that the primary goal of post-authoritarian governments was to bring inflation under control. The process of stabilization was however a long drawn out affair. After a number of unsuccessful anti-inflationary programs, it was the Real Plan implemented in the early 1990s that was instrumental in stabilizing price levels. The plan included reduction of fiscal deficits through tax increases, cuts in government spending, and the privatization of state owned firms (Saad-Filho, 2010). An integral part of the stabilization program was the use of exchange rates as a tool for inflation management 
(Baer, 2014). Though highly effective for controlling prices, maintaining overvalued exchange rates also necessitated extremely high interest rates which had a deflationary effect on the economy. Figure 2 shows just how high Brazilian interest rates have been when compared to India. On the whole, therefore the results of these stabilization policies were mixed. On the negative side table 2 indicates that the deflationary policy stance curtailed investment rates and dampened GDP growth. As far as the labour markets were concerned, there was a trend towards greater labour market flexibility and employment growth remained low even while wage shares declined (Serrano and Summa, 2011; Baltar et. al., 2010). On the positive side the Real Plan brought control over inflation and this provided much needed macroeconomic stability. Moreover despite curtailment of fiscal deficits, social spending actually increased (Hall 2006). This new found stability, combined with pro-poor government intervention led to slow declines in poverty and inequality during the second half of the 1990's and improvements in school enrolments (De Souza, 2012; Serrano and Summa, 2011).

Figure 2: Real Interest Rate \%

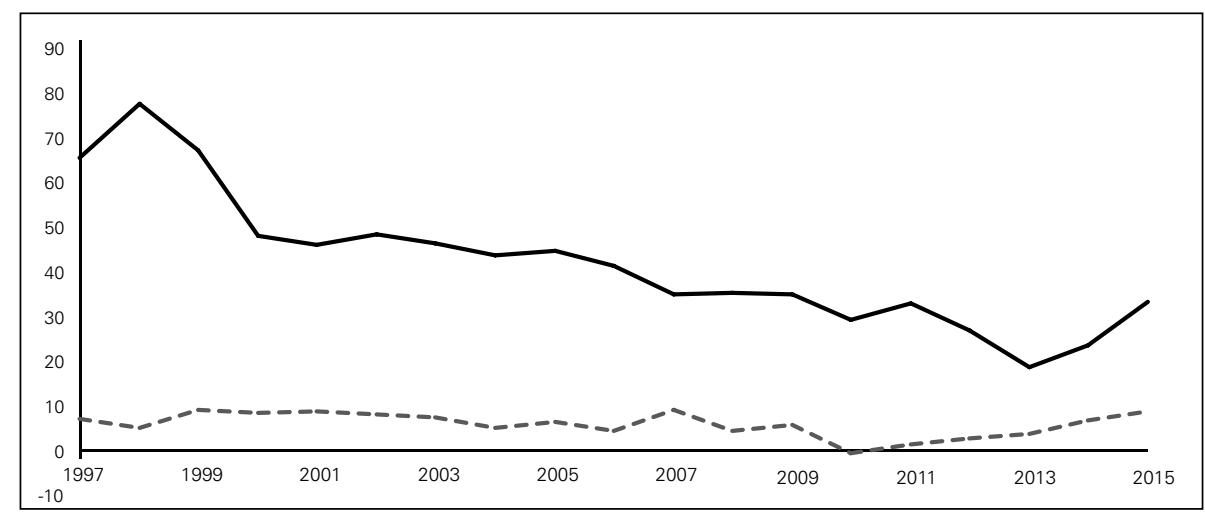

Source: World Development Indicators (Online)

2002 marked an important moment in the economy. The electoral victory of the PT headed by Luiz Inácio Lula da Silva witnessed the beginning of a new phase of policy making. Between 2000 and 2010 the economy grew at 3.7 percent per annum, which modest from India's perspective, was nonetheless much higher than its growth rates during the 1990s (Table 2). However unlike the Indian case, this growth was largely led by broad based increases in household incomes (ILO, 2011). Interestingly this period of growth coincided with a larger role of the state in the economy. Privatizations that were initiated under the previous regime were not dismantled but the process of privatization came to a halt under the PT regime (Anderson, 2011). Moreover, despite curbs on fiscal deficits (associated with the inflation targeting regime in place) the govern- 
ment actually weakened its fiscal surplus targets (Ban 2013). The extent of state intervention can also be gauged by its social activism. Berg (2010) notes that minimum wages increased from 266R \$ to 510R \$ between 2000 and 2010 and according to ILO (2011) total social-sector spending as a percentage of GDP amounted to 26 percent in Brazil in 2008 (it was below 10 percent in India). From a comparative perspective these changes are indeed impressive. For example public investments in education and health in Brazil amounted to 5.8 percent of GDP and 4.5 percent of GDP in 2012 while in India the numbers were 3.3 percent and 1.2 percent respectively. What is heartening about these changes is that many of the government's safety-net programs are increasingly taking a quasi-universal form (Huber and Stephens, 2012). The number individuals covered under the celebrated Bolsa Familia program, for instance, has more than tripled in 2003-12 while disbursements have quadrupled during the same period (Weisbrot et al., 2014).

An important aspect of the recent phase of development has been the substantial improvement in the status of labour. The economy added 20 million jobs in the first decade of the $21^{\text {st }}$ century which was almost double the amount that was added the previous decade (Saad-Filho and Morais, 2013). Berg (2010 p. 10) also notes that "Formal jobs grew at an annual rate of 5.3 percent, whereas informal job creation fell to 1.7 percent annually". Interestingly these increases in employment have gone hand in hand with increases in real wages. This brings us to perhaps the most impressive aspect of Brazil's recent economic growth. Despite a decline in wage shares across the world, Brazil has bucked the trend and the share of wages in national income has shown sustained increases from 2004 onwards (Serrano and Summa, 2011).

As a result of all these policies there has been a decline in poverty and inequality. Saad-Filho and Morais (2013 p. 233) note that "The incomes of the bottom decile rose by 91 percent between 2001 and 2009, while the incomes of the top decile increased by a more modest 16 percent”. Between 2001 and 2012 poverty has declined by $65 \%$ (from $24.3 \%$ of the population to $8.4 \%$ ) and extreme poverty has fallen by over $70 \%$ (from $14 \%$ of the population to $3.5 \%)$. Given the inherent problems associated with poverty calculations we may also note other indicators of progress. In the 12 year period spanning 2000 and 2012, mean years of schooling increased by 1.6 years, life expectancy has increased by 3.4 years and the under- 5 mortality rate has decreased at an average rate of $6.9 \%$ per year. As far as education is concerned the increase in educational attainment has also been associated with declines in the educational inequalities (Drèze and Sen, 2013).

It should be noted that any attempt to neatly categorize Brazilian development in one form or the other is bound to be controversial. Not only are the empirical realities too complex but the political debates surrounding Brazil's economy indicate that economic change has been an intensely conflictual and 
contradictory process. The economic and political crisis facing the nation today adds to these uncertainties and paints a grim picture of its future prospects. While appreciating these complexities, a comparative perspective nonetheless also forces us to recognize the radical potentialities of the Brazilian developmental regime. More specifically, in a globalized world where the quest for competitiveness has been driving down wages and employment across developed regions Brazil has been able to resist assaults on its labour force. The mere act of strengthening labour rights in a financialized world represents an act of great defiance against global finance and it symbolizes reclamation of public institutions from the grips of elite interests. Thus even if Brazil's current trajectory does not represent a sharp departure from its past, its current path is still a far cry from the predatory models adopted in other parts of the world.

\section{THE POLITICAL ECONOMY OF GROWTH REGIMES: A COMPARATIVE ANALYSIS OF BRAZIL AND INDIA}

The discussion on Brazilian and Indian growth regimes raises some interesting questions. In both countries neoliberalism was adopted as a response to the exhaustion of import substitution. Both transitions occurred in countries which were political democracies, which meant that political classes in both countries were subject to similar types of popular pressures. Added to all this, these transitions occurred during a period when the world economy itself was undergoing tectonic shifts. The puzzle here therefore is that despite facing similar conditions the two economies have ended up embracing very distinct approaches to development. Viewing India from a Brazilian perspective the central question that arises is why, despite similar constraints, were the Indian elites successful in thrusting an exclusionary pattern of economic growth? To put it differently, what were the distinctive features of the Brazilian political economy that tempered its policies and allowed it to shift away from the anti-labour stance that neoliberal policies are often associated with? This is the central puzzle that this section seeks to analyze.

It has been widely argued that the stability and durability of any mode of accumulation depends on the extent to which politically and economically dominant classes are able to draw support from broad sections of the society. This argument goes back to Gramsci, but the idea has resurfaced in several forms in recent studies of European and Latin American economies as well (Bresser-Pereira and Ianoni, 2015; Chodor, 2015). As far as liberalizing Latin American economies are concerned, Chodor (2015) argues that the neoliberal order has proved to be unstable because dominant classes that control the state have failed to create a broad enough social support base. For Chodor (2015) 
the main problem lies in the fact that neoliberalism, as applied to Latin American economies, lacks a "plausible development strategy". As a result of this not only have the working classes been excluded from the entire project but vast sections of the traditional elites- including the national industrial bourgeoisie- have found themselves on the losing side of the liberal policypackage. Now what is true about Latin America holds for India as well, but with a few important differences. As has been discussed in the previous sections, the entire pro-capital project in India has marginalized vast sections of the society. But unlike many Latin American economies, Indian reforms have allowed the economy to grow at a fast pace. By providing sufficient room for economic growth these policies have benefitted large sections of the propertied elites. Thus even though the neoliberal social coalition remains narrow, on a comparative level the pro-capital stance has nonetheless been able to bring together disparate factions of propertied elites thereby providing a greater degree of cohesiveness amongst constituents of the dominant bloc. This in turn has allowed dominant classes to push the state to adopt a highly elitist trajectory benefitting this small privileged minority. Figure 3 shows a schematic representation of the mechanism. Obviously the difference between the Indian and Brazilian experiences cannot simply be reduced to differences in the rates of economic growth. The distribution of economic gains amongst different factions of the dominant coalition is an important factor, but solving collective action problems requires more than just similar economic interests; it requires shared cultural and ideological values as well. It is here that political parties play an important role. Political parties codify common ideological and cultural values and by doing so, they act as crucial mechanisms through which class interests are constructed and articulated (Huber and Stephens, 2012; Desai, 2012). Here again, Brazil and India are striking contrasts. In Brazil the neoliberal era has witnessed the rise of programmatic leftist parties like the PT which have been successful in consolidating social support in favor of pro-poor policies. In India on the other hand, in the last two decades there has been a shift towards the right in the political sphere. The most important political actor in this regard is the BJP (Bharatiya Janata Party) which, along with its allies, has successfully combined the rhetoric of religious nationalism with the economics of elitism and has become a crucial vehicle for naturalizing the pro-capital project.

The following section traces out the political economy of growth regimes in Brazil and India and tries to shed light on the questions raised previously. 


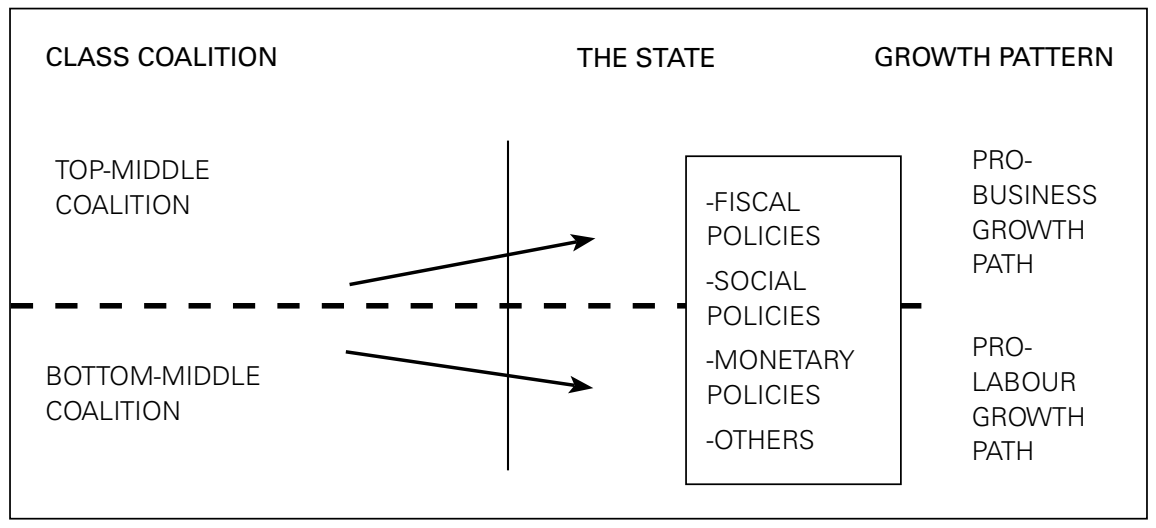

India

India's neoliberal turn occurred under conditions that were very different from Brazil's. By the early 1980's economic growth had picked up, ending a decade of stagnation. Moreover unlike Brazil, in India inflation rates were stable throughout this period. According to some estimates GDP and productivity growth rates during the 1980s may have even exceeded the growth rates registered in the 1990s (Kohli, 2006a, 2006b; Rodrik and Subramanian, 2004; McCartney, 2009). Added to strong economic performance at the national level, the international context was very favorable. "Transnational banks were flushed with recycled petro-dollars and eager to lend" (McCartney 2010 p. 52). With low levels of foreign debt and a relatively stable economy, foreign finance was easy to come by for India. Of course it is true that the economy had a balance of payment crisis in 1990 but as Patnaik and Chandrasekhar (1995) suggest, the actual dimensions of this crisis never reached threatening proportions and there was actually very little need to resort to liberalization. What all this means is that the neoliberal reforms were not undertaken in response to external shocks as was the case of Brazil; It was a slow and gradual process which by this virtue has succeeded in creating of a strong coalition of support, including not only the big bourgeoisie but also the urban middle class and propertied middle and upper castes of rural India.

As far as big capitalists were concerned, liberalization allowed better access to new technologies and foreign finance. The sequential nature of the process also ensured that the national capitalists were shielded from the sort of denationalization that Brazilian industries were forced to undergo (Mazumdar 2011). Further, unlike Brazil where taming inflation created a propensity towards deflationary policies during the 1990s and therefore caused significant losses of jobs for the middle class, in India not only was neoliberal policymaking rela- 
tively less conservative but the aforementioned bias towards high-tech services also tipped the scale in favor of skilled labour. The burgeoning opportunities in India's knowledge economy has been particularly beneficial for the highly educated urban middle classes and has made them a vocal supporter of India's new economic policies (Fernandes and Heller, 2006). Added to this, the incorporation of agrarian elites, especially those belonging to land-owning, middle-castes within the dominant bloc has played an important role in buttressing support for the new economic stance. This point should be treated with caution because neoliberal policies have undoubtedly been prejudicial to the agricultural sector and there has been severe opposition to liberal policies from various rural classes because of the threats to state subsidies that liberalization entails. With this caveat in mind it is also true that for many land-owning middle-castes India's new economic stance has proved to be a boon. Desai (2007 p. 795) explains that in the wake of the commercialization that followed the green revolution of the 1960s "An originally agrarian bourgeoisie became a provincial propertied class". Over time this new provincial propertied elite successfully diversified its investments by investing heavily in educational institutions and a wide variety of urban industries and services (Kamat, 2011; Upadhya, 1988). The effect of this, according to Desai (2007 p. 795), was that this new provincial elite became “... the main avenue through which surpluses created in agriculture were transferred by individual capitalists diversifying out of agriculture-to the urban and industrial sector". Therefore despite its seeming disadvantage, "This class is now part of a relatively seamless bourgeois class that stretches from the villages to the country's 'metros' and beyond it to the class of non-resident Indian (NRI) expatriate propertied class" (Desai, 2007 p. 795).

Apart from common economic interests, the cohesiveness of the dominant bloc has been aided by the rise of "communal fascism" in Indian politics. Starting from the 1970s this ascendancy of parties openly espousing religious nationalism has provided- to use Hobsbawm's phrase- the ideological cement for uniting a wide spectrum of dominant classes (Sridharan, 2014; Desai, 2014a, $2014 \mathrm{~b})$. The most prominent amongst these parties is the BJP which has been a keen supporter of neoliberal reforms and has gained immense popularity by using its own, indigenous brand of religious nationalism (Hindutva). Parties like the BJP have not only coalesced propertied classes around the neoliberal agenda, but they have also been crucial for splintering any potential opposition. In an insightful study, Varshney (1998) has argued that the introduction of neoliberal policies went ahead without any significant resistance partly because potential opponents were too distracted by ethnic violence perpetrated by communal organizations. The growing specter of communalism meant that neoliberal reforms became a concern of "elite politics" and communal conflagrations came to dominate "mass politics" and this provided enough room for the governing coalition to introduce economic reforms. Contemporary political chang- 
es have confirmed the crucial role played by communalism in pushing ahead with the pro-capital project. Labor unions affiliated with the right-wing have supported core neoliberal programs and have consistently fragmented labor on ethnic lines which has made collective action more difficult (Desai, 2012; Sengupta, 2009). The most recent elections in India have voted into power a political alliance of right-wing Hindu outfits (headed by the BJP) that have openly used ethnic nationalism as a tool for popular mobilization. What is important to note however, is that the drumming up of nationalistic fervour has gone hand in hand with the promotion of blatantly elitist policies. All this suggests that the combination of political obscurantism and neoliberalism is fast becoming the new equilibrium of neoliberal-India.

\section{Brazil}

In the case of Brazil neoliberal reforms of the 1990s were preceded by massive economic dislocation due to a dual assault of the debt crisis and a fourdigit inflationary upsurge. On the political side the in-egalitarian policies of the military state together with its impotence to control the downward economic slide delegitimized authoritarian rule. Social discontent fueled massive grass root mobilization from across the society. Within this multi-class opposition, labour movements emerged as important players. Labour militancy was aided by the rise of a novel mode of organization, often termed new-unionism. Representatives of new-unionism viewed the corporatist structure of industrial relations as a major threat to their interests and accordingly demanded greater autonomy of unions from the state (Seidman, 1994). This however did not prevent them from demanding greater representation in political institutions. The entire transitional process had convinced the working classes that economic transformations in favor of the poor would be impossible without gaining access to the state apparatus. As Lula argued: "The economic and political are two factors that we cannot disentangle from each other. They are two very interconnected things..." (quoted in Seidman, 1994 p. 164). Not surprisingly representatives of social movements and unions took extensive part in drafting the new constitution and were influential in shaping many social policies during the 1990s (Heller, 2013).

The establishment of a programmatic left party in the form of PT provided a further impetus to the political aspirations of the labour movement. The role of the PT in Brazil's economic regime has to be placed in perspective. It is undoubtedly true that from the very beginning the Brazilian version of neoliberalism had an unorthodox bent, in the sense that welfare policies were given great importance. But in terms of actual outcomes the performance of the social sector during the 1990s was disappointing. It was here that the emergence of PT as a national political force was very crucial. It's coming to power in 2002 
marked the beginning of a clear and unambiguous shift in Brazil's economic trajectory. Established in 1980, PT provided a broad political platform for bringing together various factions of the Brazilian Left. While the party drew heavily from the ranks of industrial labour, it was able to attract individuals from a wide variety of civil society movements and base communities as well (French and Fortes, 2005). This mass base meant that whereas in 1982 it was able to garner a vote share of $3 \%$, less than a decade later in the elections of 1989 the presidential candidate of PT managed to obtain $43 \%$ of the vote in the second round (French and Fortes, 2005). Though it was only in 2002 that PT tasted electoral success, its principled criticism of liberalization policies throughout the 1990s earned it support from the poorest and propelled it into a big force in national politics. Since 2002 PT has been instrumental in deepening economic democracy and although it has eschewed a frontal attack on land relations and property rights, under its watch inequalities have declined and opportunities for decent work have increased.

This brings us to an important feature of the Brazilian neoliberal experience - the neoliberal reforms of the 1990s fell especially hard not only on workers but - at least in a relative sense- also on Brazilian industrialists, agrarian exporters and middle classes. With the crushing debt-cum-inflationary crisis still a part of public memory, the economic regime of the post-1990s period prioritized stability over growth. This was done by adopting a deflationary economic stance consisting of high-interest rates and uncompetitive exchange rates (See Figure 2). Under the guise of restoring macroeconomic stability the high-interest rate regime greatly benefitted financial capital while industrial production and agrarian sectors suffered. The prioritization of rentier interests over the real sector, in turn, created major faults within the ranks of the Brazilian elite (Boito, 2007). As far as the middle classes were concerned, Saad-Filho (2013 p. 662), while circumspect about the ideological inclinations, nonetheless states that "While large capital did well economically over the last decade or more, the middle class did not share in this prosperity. So-called 'good jobs' in the private and public sectors are relatively scarce, higher education no longer guarantees 'good' income, and the young find it hard to do better economically than their parents". In sum, the deflationary policies of the $1990 \mathrm{~s}$ prevented the emergence of a stable neoliberal coalition and actually created cleavages even within the Brazilian elites themselves. Disillusioned with orthodox policies, by 2002 it was precisely this "'losers' alliance" consisting of workers, local industrialists and middle classes that began demanding a change from status quo and that propelled PT into the national limelight (Morais and Saad-Filho, 2003). The elections of 2002 represented a strong aspiration for change amongst various classes and categories of Brazilians, but ultimately the rise of the PT represented a victory for the poorest and most marginalized sections of society that had borne the brunt of Brazil's historical legacies of inequality and 
poverty. In the new phase of policy making even though economic orthodoxies may not have been completely dismantled but the nature of the political verdict also ensured a clear shift towards a fairer economic regime.

\section{CONCLUSION}

This paper compares the development regimes of Brazil and India during the neoliberal era. In the case of Brazil labour market interventions (minimum wages, employment creation in the formal sector etc.), income redistribution schemes and public investments in human capital have created an inclusive process of growth. In the case of India, the developmental approach has promoted an exclusionary form of growth where the very process of growth has become contingent on wage declines and low employment growth.

In order to explain why the two countries have followed such distinct paths this paper analyzes some important differences between the two. The central argument that is made here is that in India neoliberalism was carried out gradually and sequentially. By the virtue of this gradualism, big capital- which was itself becoming increasingly transnational- was able to build a coalition of support which included, amongst others, the small, but vocal urban middle class and politically influential sectors of the land-owning peasantry. The construction of a cohesive dominant bloc was aided by the rise of religious nationalist parties like the BJP who were successful in embedding pro-capital policies and fracturing political opposition. In contrast in Brazil, neoliberalism was undertaken within the context of a severe economic crisis. As a result during the post-1985 period controlling debt, reducing inflation and achieving macroeconomic stability assumed greater importance than economic growth. Conservative economic policies adversely affected the poorer classes, local industrialists and the urban middle classes. The widespread disaffection was given political voice by various social movements and pro-labour parties which had sprung up during the 1980s. The most important of these was the PT which came into power in 2002 and which, since its ascension to power, has been a crucial vehicle of institutionalizing pro-poor policies.

\section{REFERENCES}

Abreu, M.D.P. (2004). “The Political Economy of High Protection in Brazil before 1987. Special Initiative on Trade and Integration”, Working Paper SITI-08A. Retrieved from: https://publications. iadb.org/handle/11319/2641?locale-attribute=en [Viewed: 12/12/2015]

Ahluwalia, Montek S. (2002). "Economic Reforms in India since 1991: Has Gradualism Worked?”. The Journal of Economic Perspectives, 16(3): 67-88.

Ahn, Pong-Sul (2010). The Growth and Decline of Political Unionism in India: The Need for a Paradigm Shift. ILO. 
Anderson, Perry. (2011). “Lula’s Brazil”. London Review of Books, 33(7): 3-12.

ADB (2011) Understanding Poverty in India. Asian Development Bank

Baer, Werner and Sirohi, Rahul A. (2016). "Industrialization and de-industrialization in emerging economies: The case of Brazil and India". Unpublished manuscript.

Baer, Werner (2014) The Brazilian Economy: Growth and Development, 7th ed, Boulder: Lynne Reinner.

Baltar, Paulo Eduardo de Andrade, Dos Santos, Anselmo Luís, Krein, José Dari, Leone, Eugenia., Proni, Marcelo Weishaupt., Moretto, Amilton, Maia, Alexandre Gori \& Salas, Carlos (2010) "Moving Towards Decent Work. Labour in the Lula Government: Reflections on Recent Brazilian Experience", Global Labour University Working Paper No. 9.

Ban, Cornel (2013) "Brazil's liberal neo-developmentalism: New paradigm or edited orthodoxy?", Review of International Political Economy, 20(2): 298-331.

Ban, Cornel \& Blyth, Mark (2013) The BRICs and the Washington consensus: An Introduction. Review of International Political Economy, 20(2): 241-255.

Bardhan, Pranab. (1999). The Political Economy of Development in India: Expanded edition with an epilogue on the political economy of reform in India. OUP Catalogue.

Berg, Janine (2010) "Laws or luck? Understanding rising formality in Brazil in the 2000s", Decent Work in Brazil Series Working Paper No. 5, ILO. Retrieved from: http://mpra.ub.uni-muenchen. de/43608/1/MPRA_paper_43608.pdf [Viewed: 12/12/2015]

Bhaduri, Amit. (2008). "Predatory Growth". Economic and Political Weekly, 43(16): 10-14.

Bohn, Simone R. (2011) "Social Policy and Vote in Brazil: Bolsa Família and the Shifts in Lula's Electoral Base". Latin American Research Review, 46(1): 54-79.

Boito, Armando. (2007) Class Relations in Brazil's New Neoliberal Phase, Latin American Perspectives, 34(5): 115-131.

Bresser-Pereira, Luiz Carlos \& Ianoni, Marcus (2015) "Developmental Class Coalitions: Historical Experiences and Prospects”, Textos para Discussão da Escola de Economia de São Paulo da Fundação Getulio Vargas No. 386. Retrieved from: http://www.bresserpereira.org.br/view. asp?cod=6002 [Viewed: 12/12/2015]

Bresser-Pereira, Luiz Carlos (1990). The perverse logic of stagnation: debt, deficit, and inflation in Brazil. Journal of Post Keynesian Economics, 12 (4): 503-518.

Bresser-Pereira, Luiz Carlos (1984) Development and Crisis in Brazil, 1930-1983. Westview Press.

Chandrasekhar, C.P. (2010) "From dirigisme to neoliberalism: Aspects of the Political Economy of the Transition in India", Development and Society, 39(1): 29-59.

Chandrasekhar, C. P. and Ghosh, Jayati. (2011). India: The Latest Employment Trends from the NSSO. Monthly Review, Retrieved from: http://mrzine.monthlyreview.org/2011/cg240711.html [Viewed: 12/12/2015].

Cheng, Hui Fang, Gutierrez, Margarida, Mahajan, Arvind, Shachmurove, Yochanan \& Shahrokhi, Manuchehr (2007) "A Future Global Economy to be built by BRICs", Global Finance Journal, 18(2): 143-156.

Chodor, Tom (2015) Neoliberal Hegemony and the Pink Tide in Latin America: Breaking Up With TINA?. Palgrave Macmillan.

Corbridge, S., and Harriss, J. (2000). Reinventing India: Liberalization. Hindu Nationalism and Popular Democracy, Polity Press.

Desai, Manali (2012) "Parties and the Articulation of Neoliberalism: From "The Emergency" to Reforms in India, 1975-1991", In Julian Go (ed.) Political Power and Social Theory (Political Power and Social Theory, Volume 23) Emerald Group Publishing Limited

Desai, Radhika (June 27, 2014a) “India's Saffron Capitalism” Counterpunch, Retrieved from: http:// www.counterpunch.org/2014/06/27/indias-saffron-capitalism/ [Viewed: 12/12/2015]

Desai, Radhika (2014b). “A latter day fascism?”, Economic and Political Weekly, 49(35), 48-58

Desai, Radhika (2007) "Dreaming in Technicolour? India as a BRIC economy” International Journal, 62(4): 781-804.

De Souza, Pedro H. G. Ferreira (2012) "Poverty, inequality and social policies in Brazil, 1995-2009", Working Paper No. 87, International Policy Centre for Inclusive Growth.

Drèze, Jean (May, 2015). India's Rural Jobs Programme: A Dismal Appraisal. Huffingtonpost. Availa- 
ble at: http://www.huffingtonpost.in/jean-draze/nrega-a-dismal-appraisal_b_7202650.html [Viewed: 21/03/2016]

Drèze, J., \& Sen, A. (2013). An uncertain glory: India and its contradictions. Princeton University Press. FAO, IFAD and WFP. (2014) The State of Food Insecurity in the World, 2014:

Strengthening the Enabling Environment for Food Security and Nutrition, Rome, FAO.

Fernandes, Leela, \& Heller, Patrick (2006) "Hegemonic Aspirations: New Middle Class Politics and India's Democracy in Comparative Perspective”, Critical Asian Studies, 38(4): 495-522.

French, John D. \& Fortes, Alexandre (2005) "Another World is Possible: The Rise of the Brazilian Workers' Party and the Prospects for Lula's Government”, Labor, 2(3): 13-31.

Ghani, Ejaz (2010). The Service Revolution in South Asia, Oxford University Press, India.

Goldar, Bishwanath (1986) "Import Substitution, Industrial Concentration and Productivity Growth in Indian Manufacturing”, Oxford Bulletin of Economics and Statistics, 48(2): 143-164.

Guha, Ramachandra (2008) India after Gandhi: The History of the World's Largest Democracy. Picador India.

Hall, Anthony (2006) "From Fome Zero to Bolsa Família: Social Policies and Poverty Alleviation Under Lula", Journal of Latin American Studies, 38(4): 689-709.

Heller, Patrick (2013) "Challenges and Opportunities: Civil Society and Social Movements in a Globalizing World”, UNDP Human Development Report Office Occasional Paper 2013/06.

Huber, Evelyne \& Stephens, John D. (2012) Democracy and the Left: Social Policy and Inequality in Latin America. University of Chicago Press.

IFPRI (2014). 2014 Global Hunger Index: The Challenge of hidden hunger. IFPRI

ILO (2011) Brazil: An innovative Income-Led Strategy. Studies on Growth with Equity, ILO, International Institute for Labour Studies

ILO (2010) World of Work Report 2010: From One Crisis to the Next? ILO, International Institute for Labour Studies

Kamat, Sangeeta (2011) "Neoliberalism, Urbanism and the Education Economy: Producing Hyderabad as a 'global city'”, Discourse: Studies in the Cultural Politics of Education, 32(2): 187-202.

Kochhar, K., Kumar, U., Rajan, R., Subramanian, A., \& Tokatlidis, I. (2006). India's pattern of development: What happened, what follows?. Journal of Monetary Economics, 53(5), 981-1019.

Kohli, Atul. (2012). Poverty amid plenty in the new India. Cambridge University Press.

Kohli, Atul (2006a). Politics of Economic Growth in India, 1980-2005: Part I: The 1980s. Economic and Political Weekly, 41(13): 1251-1259.

Kohli, Atul (2006b). Politics of economic growth in India, 1980-2005: Part II: The 1990s and beyond. Economic and Political Weekly, 41(14): 1361-1370.

Lavoie, Marc, and Stockhammer, Engelbert (2012) "Wage-led Growth: Concept, Theories and Policies", Conditions of Work and Employment Series No. 41, ILO.

Maiorano, Diego (2014) "Continuity amid Change in India's Political Economy From 1980 to 2004". Economic and Political Weekly, 49( 9)

Mazumdar, Surajit (2011) "Continuity and Change in Indian Capitalism”, MPRA Paper No. 38907.

McCartney, Matthew (2010) Political Economy, Growth and Liberalisation in India, 1991-2008. Routledge.

McCartney, Matthew (2009). “'Episodes' or 'Evolution'The Genesis of Liberalisation in India”. Journal of South Asian Development, 4(2), 20267-2868.

McMillan, Margaret S. and Rodrik, Dani (2011) "Globalization, Structural Change and Productivity Growth”, Working Paper No. w17143, National Bureau of Economic Research.

Mehrotra, S., Gandhi, A., Saha, P., \& Sahoo, B. K. (2012). Joblessness and informalization: Challenges to inclusive growth in India. IAMR Occasional Paper No. 9.

Mohan, Rakesh (2008) "Growth Record of the Indian Economy, 1950-2008: A Story of Sustained Savings and Investment”, Economic and Political Weekly 43(19): 61-71.

Morais, Lecio, \& Saad-Filho, Alfredo (2003) "Snatching Defeat from the Jaws of Victory? Lula, the 'Losers' Alliance', and the Prospects for Change in Brazil”, Capital \& Class, 27(3): 17-23.

Patnaik, Prabhat (2013). Modern India sans the Impact of Capitalism. Economic and Political Weekly, 48 (36): $30-35$

Patnaik, Prabhat (2007) “The State under Neo-liberalism”, Social Scientist, 35(1/2): 4-15 
Patnaik, Prabhat., and Chandrasekhar, C. P. (1995) “Indian Economy under 'Structural Adjustment'”, Economic and Political Weekly, 30 (47): 3001-3013.

Patnaik, Utsa (2010) “Trends in Urban Poverty under Economic Reforms: 1993-94 to 2004-05”, Economic and Political Weekly, 45(4): 42-53.

Patnaik, Utsa (2007). Neoliberalism and Rural Poverty in India. Economic and Political Weekly, 42(30): 3132-3150.

Ravallion, Martin (2011) “A Comparative Perspective on Poverty Reduction in Brazil, China, and India”, World Bank Research Observer, 26(1): 71-104.

Ray, Ranjan (2007) "Changes in food consumption and the implications for food security and Undernourishment: India in the 1990s", Development and Change, 38(2): 321-343.

Rodrik, Dani., \& Arvind Subramanian. (2004). From" Hindu growth" to productivity surge: the mystery of the Indian growth transition. National Bureau of Economic Research, Working Paper No. 10376

Saad-Filho, Alfredo, \& Morais, Lecio. (2013). Mass protests: Brazilian spring or Brazilian malaise?. Socialist Register, 50(50). 227-246.

Saad-Filho, Alfredo (2013). Mass protests under 'left neoliberalism': Brazil, june-july 2013. Critical Sociology, 39(5), 657-669.

Saad-Filho, A (2010). Neoliberalism, Democracy and Development Policy in Brazil, Development and Society, 39(1): 1-28.

Sainath, P (Feb 12, 2009) "Neo-Liberal Terrorism in India: The Largest Wave of Suicides in History" Counterpunch, Retrieved from: http://www.counterpunch.org/2009/02/12/the-largest-wave-of-suicides-in-history/ [Viewed: 12/12/2015]

Sarkar, Sumit (2008). "Nationalism and poverty: discourses of development and culture in 20th century India”. Third World Quarterly, 29(3), 429-445.

Sarkar, Sumit (2001). "Indian Democracy: the Historical Inheritance”, in Kohli, Atul (ed.) The Success of India's Democracy, Cambridge University Press.

Seidman, Gay W. (1994) Manufacturing militance: workers' movements in Brazil and South Africa, 1970-1985. Univ of California Press.

Sen, Amartya (1993) "The Threats to Secular India”, Social Scientist, 21 (3/4): 5-23.

Sengupta, Mitu (2009) "Economic liberalization, democratic expansion and organized labour in India: towards a new politics of revival?”, Just Labour: A Canadian Journal of Work and Society, 14: 13-32.

Serrano, Franklin and Summa, Ricardo (2011). "Macroeconomic Policy, Growth and Income Distribution in the Brazilian Economy in the 2000s." Washington, DC: Center for Economic and Policy Research.

Sridharan, Eswaran (2014) "Class Voting in the 2014 Lok Sabha Elections". Economic \& Political Weekly, 49(39): 72-76.

UNICEF (2014). The State of the World's Children 2014 in Numbers: Revealing Disparities, Advancing Children's Rights: Every Child Counts. United Nations.

Upadhya, Carol B. (1988) “The Farmer-Capitalists of Coastal Andhra Pradesh", Economic and Political Weekly, 23(28): 1433-1442.

Varshney, Ashutosh (1998) "Mass Politics or Elite Politics? India's Economic Reforms in Comparative Perspective. Journal of Policy Reform, 2(4): 301-335.

Vinaik, Achin. (2001). The New Indian Right, New Left Review 9.

Williamson, John, \& Zagha, Roberto (2002) "From the Hindu rate of growth to the Hindu rate of Reform", SCID Working Paper 144.

Weisbrot, Mark, Johnston, Jake and Lefebvre, Stephan (2014) "The Brazilian Economy in Transition: Macroeconomic Policy, Labor and Inequality”, CEPR Report. Washington, DC: Center for Economic and Policy Research. 


\section{ERRATA}

In the paper "Alternate paths to economic development: A comparative analysis of Brazil and India in the era of neoliberalism"

DOI: 10.1590/0101-31572017v37n02a03, published in the Brazilian Journal of Political Economy 147, vol. 37, n.2, April-June/2017, originally published in this site, some footnotes failed to be published:

\section{Where it read:}

[...] This capital intensive nature of structural change, while growth inducing, has been unsuccessful in absorbing the large pool of unskilled labour that exists in the countryside. Thus while the share of services accounted for $53 \%$ of GDP in 2010, its share in total employment was a mere $26 \%$. Agriculture on the other hand employed 55\% of the labour force, but accounted for only 16 $\%$ of GDP in the same year.

\section{Read:}

[...] This capital intensive nature of structural change, while growth inducing, has been unsuccessful in absorbing the large pool of unskilled labour that exists in the countryside. Thus while the share of services accounted for $53 \%$ of GDP in 2010, its share in total employment was a mere $26 \%$. Agriculture on the other hand employed 55\% of the labour force, but accounted for only 16 $\%$ of GDP in the same year. ${ }^{5}$

\footnotetext{
${ }^{5}$ Baer and Sirohi (2016) develop this argument in detail for Brazil and India. See Ghani (2010) for a different conclusion.
}

\section{Where it read:}

[...] The cumulative result of the Indian pattern of development has been a relatively poor performance on the social front

\section{Read:}

[...] The cumulative result of the Indian pattern of development has been a relatively poor performance on the social front. ${ }^{6}$

${ }^{6}$ See Drèze and Sen (2013) and Kohli (2012) for a brief discussion.

\section{Where it read:}

[...] UNICEF estimates that three out of ten stunted children in the world come from India and IFPRI's food hunger index places India along with countries facing "serious" rates of hunger.

\section{Read:}

[...] UNICEF estimates that three out of ten stunted children in the world come from India ${ }^{7}$ and IFPRI's food hunger index places India along with countries facing "serious" rates of hunger.

\footnotetext{
${ }^{7}$ http://unicef.in/Story/1124/Nutrition.
} 


\section{Where it read:}

[...] For example public investments in education and health in Brazil amounted to 5.8 percent of GDP and 4.5 percent of GDP in 2012 while in India the numbers were 3.3 percent and 1.2 percent respectively.

\section{Read:}

[...] For example public investments in education and health in Brazil amounted to 5.8 percent of GDP and 4.5 percent of GDP in 2012 while in India the numbers were 3.3 percent and 1.2 percent respectively ${ }^{8}$.

${ }^{8}$ United Nations Human Development Report (online): http://hdr.undp.org/en/data and World Development Indicators (online): http://data.worldbank.org/data-catalog/world-development-indicators [Viewed: 30/06/2015].

\section{Where it read:}

[...] Between 2001 and 2012 poverty has declined by $65 \%$ (from $24.3 \%$ of the population to $8.4 \%$ ) and extreme poverty has fallen by over $70 \%$ (from $14 \%$ of the population to $3.5 \%$ ).

\section{Read:}

[...] Between 2001 and 2012 poverty has declined by $65 \%$ (from $24.3 \%$ of the population to $8.4 \%$ ) and extreme poverty has fallen by over $70 \%$ (from $14 \%$ of the population to $3.5 \%)^{9}$.

${ }^{9}$ FAO, IFAD and WFP (2014).

\section{Where it read:}

[...] Given the inherent problems associated with poverty calculations we may also note other indicators of progress. In the 12 year period spanning 2000 and 2012, mean years of schooling increased by 1.6 years, life expectancy has increased by 3.4 years and the under- 5 mortality rate has decreased at an average rate of $6.9 \%$ per year.

\section{Read:}

[...] Given the inherent problems associated with poverty calculations we may also note other indicators of progress. In the 12 year period spanning 2000 and 2012, mean years of schooling increased by 1.6 years, life expectancy has increased by 3.4 years and the under- 5 mortality rate has decreased at an average rate of $6.9 \%$ per year $^{10}$.

${ }^{10}$ In India the corresponding numbers were 0.8 years, 4.1 years, $4 \%$ per year respectively. See UNICEF (2014) and UNDP (online): http://hdr.undp.org/en/data. 


\section{Where it read:}

[...] Of course it is true that the economy had a balance of payment crisis in 1990 but as Patnaik and Chandrasekhar (1995) suggest, the actual dimensions of this crisis never reached threatening proportions and there was actually very little need to resort to liberalization. What all this means is that the neoliberal reforms were not undertaken in response to external shocks as was the case of Brazil; It was a slow and gradual process which by this virtue has succeeded in creating of a strong coalition of support, including not only the big bourgeoisie but also the urban middle class and propertied middle and upper castes of rural India.

\section{Read:}

[...] Of course it is true that the economy had a balance of payment crisis in 1990 but as Patnaik and Chandrasekhar (1995) suggest, the actual dimensions of this crisis never reached threatening proportions and there was actually very little need to resort to liberalization ${ }^{11}$. What all this means is that the neoliberal reforms were not undertaken in response to external shocks as was the case of Brazil; It was a slow and gradual process which by this virtue has succeeded in creating of a strong coalition of support, including not only the big bourgeoisie but also the urban middle class and propertied middle and upper castes of rural India ${ }^{12}$.

${ }^{11}$ See also Vinaik (2001) and Kohli (2006a).

${ }^{12}$ Bardhan (1999) calls this the "dominant proprietary" classes.

\section{Where it read:}

[...] Further, unlike Brazil Where taming inflation created a propensity towards deflationary policies during the 1990s and therefore caused significant losses of jobs for the middle class, in India not only was neoliberal policymaking relatively less conservative but the aforementioned bias towards high-tech services also tipped the scale in favor of skilled labour.

\section{Read:}

[...] Further, unlike Brazil Where taming inflation created a propensity towards deflationary policies during the 1990s and therefore caused significant losses of jobs for the middle class, in India not only was neoliberal policymaking relatively less conservative but the aforementioned bias towards high-tech services also tipped the scale in favor of skilled labour ${ }^{13}$.

${ }^{13}$ In a somewhat exaggerated claim McCartney (2010: 95) states that "Far from providing a constraint on the fiscal maneuverability of the Indian economy and punishing deficits with capital flight, capital market liberalization has in fact allowed a sustained Keynesian-style expansion by the Indian state". Describing the state's policies as "Keynesian" can hardly by defensible given the abject failure to effective demand in any broad sense. Yet the statement also has an element of truth in the sense that even the most conservative policy makers have been relatively flexible on issues of fiscal deficit. 


\section{Where it read:}

[...] Apart from common economic interests, the cohesiveness of the dominant bloc has been aided by the rise of "communal fascism" in Indian politics.

\section{Read:}

[...] Apart from common economic interests, the cohesiveness of the dominant bloc has been aided by the rise of "communal fascism" 14 in Indian politics.

${ }^{14}$ See Sen (1993).

\section{Where it read:}

[...] So-called 'good jobs' in the private and public sectors are relatively scarce, higher education no longer guarantees 'good' income, and the young find it hard to do better economically than their parents".

\section{Read:}

[...] So-called 'good jobs' in the private and public sectors are relatively scarce, higher education no longer guarantees 'good' income, and the young find it hard to do better economically than their parents". ${ }^{15}$

${ }^{15}$ The Brazilian middle classes formed an important electoral vote base of the PT throughout the 1990's. Even though this support began to wane after the first term of Lula, PT received $60 \%$ of the lower middle class votes during the elections in 2006 (Bohn 2011).

\section{Where it read:}

[...] Disillusioned with orthodox policies, by 2002 it was precisely this "losers' alliance" consisting of workers, local industrialists and middle classes that began demanding a change from status quo and that propelled PT into the national limelight (Morais and Saad-Filho, 2003)

\section{Read:}

[...] Disillusioned with orthodox policies, by 2002 it was precisely this "losers' alliance" consisting of workers, local industrialists and middle classes that began demanding a change from status quo and that propelled PT into the national limelight (Morais and Saad-Filho, 2003) ${ }^{16}$

\footnotetext{
${ }^{16}$ Both Boito (2007) and Morais and Saad-Filho (2003) see these new class alliances as a sign of deepening, rather than weakening of neoliberalism.
} 